Original Research Paper

\title{
Relationship of Longevity with Productive and Reproductive Variables in Nelore Cows of the Bolivian Tropic
}

\author{
${ }^{1}$ Ikeda Atsuko, ${ }^{2,3}$ Barbona Ivana, ${ }^{5}$ Yoichiro Hayashi, ${ }^{6}$ Juan Antonio Pereira and ${ }^{1,2,4}$ Pablo Roberto Marini \\ ${ }^{1}$ Facultad de Ciencias Veterinarias, Universidad Nacional de Rosario, Argentina \\ ${ }^{2}$ Centro Latinoamericano de Estudios de Problemáticas Lecheras (CLEPL), Argentina \\ ${ }^{3}$ Facultad de Ciencias Agrarias, Universidad Nacional de Rosario, Argentina \\ ${ }^{4}$ Carrera del Investigador Científico (CIC-UNR) \\ ${ }^{5}$ Cooperativa Agropecuaria Integral San Juan de Yapacaní (CAISY) - Bolivia \\ ${ }^{6}$ Universidad Autónoma Gabriel Rene Moreno - Bolivia
}

Article history

Received: 06-10-2020

Revised: 30-11-2020

Accepted: 01-12-2020

Corresponding Author:

Ikeda Atsuko

PhD. Student. Facultad de

Ciencias Veterinarias,

Universidad Nacional de

Rosario, Argentina

Email: atsukoikedakatot@hotmail.com

\begin{abstract}
The objective of this study was to evaluate the relationship between longevity with productive and reproductive efficiency variables of Nelore cows in grazing systems in the Bolivian tropics. Retrospective data corresponding to the period 1992-2019, belonging to the Cooperativa Agropecuaria Integral San Juan de Yapacaní and the Foundation Technology Center on Agriculture and Livestock, Santa Cruz-Bolivia were used. The data corresponding to 774 Nelore breed cows, primiparous and multiparous discarded with a total of 4050 calvings were evaluated. The following variables were analyzed: Number of calves, live weight of cow in $\mathrm{kg}$, calf weight at birth in $\mathrm{kg}$, calf weight at weaning in $\mathrm{kg}$, total calf weight in $\mathrm{kg}$, age at first calving in months, longevity in days and calving interval in days. Cows born in the year (1985-1995) are those that arrive later to have their first calving, have a greater calving interval, have greater longevity, similar weaning weight, lower birth weight, lower live weight and higher weight total calf. While cows born in the year (2005-2015) are those that arrive younger to have their first calving, they have a shorter calving interval; have shorter longevity, similar weaning weight, higher birth weight, live weight intermediate and lower total calf weight. For the three periods analyzed, the length of life increases between 0.66-0.95 days on average when the age at first calving increases by one unit, between 1.78-2.99 days on average when the calving-calving interval increases by one unit and between 1.77-1.83 days on average when total calf weight increases by one unit. It is concluded that it was possible to find a model that explained that the greater longevity of Nelore cows in a grazing system in the Bolivian tropics was related to the older age at first calving, the greater calving interval and the greater $\mathrm{kg}$ of weights total calves.
\end{abstract}

Keywords: Length of Life, Calving Interval, Age at First Calving, Birth Weight, Weaning Weight

\section{Introduction}

Age at first calving, survival and longevity are economically important characteristics in beef cattle (Dakay et al., 2006; Carvalho et al., 2015; Damiran et al., 2018). Longevity, includes from the first to the last calving, being an economically important trait. An extension of longevity, allows increasing the number of adult cows that have a higher accumulated production
(Ikeda et al., 2020) and also reduces annual production costs, which are associated with replacement heifers and with the number of involuntary culls of cows (Rogers et al., 2004). This coincides with what was reported by (Ikeda et al., 2020) where adult Nelore cows older than five years were more productive in total $\mathrm{kg}$ of weaned calves and in reproduction than younger animals. Not achieving this distribution, the nutritional requirements are higher, because there would be more cows in a growing 
state (first and second calving cows), leaving the pregnancy relegated to the background; therefore they will be less efficient. Keeping the largest number of adult cows in the herd close to $80 \%$, would make it possible from a zoo technical concept that the traits associated with biological efficiency such as longevity and reproduction of animals produce greater sustainability of the productive system (Ikeda et al., 2020). To obtain efficient productivity in beef cows, in addition to taking into account important factors of the system, such as health aspects, age at first calving, birth and weaning weight, nutritional, reproductive and genetic factors, it is necessary to control body weight and body condition of the animals (Carrizales Montealegre, 2005; Orozco et al., 2013; Diskin and Kenny, 2014). In addition, the production of beef cattle is influenced, among other factors, by the genotype of the animal associated with the environmental conditions to which it is subjected (Holgado and Rabasa, 1999). A previous work by (Ikeda et al., 2019), showed results on the relationship between the longevity of the productive variables, in this case the parturitionparturition interval is introduced as a reproductive variable and a greater number of years of information to be able to continue deepening the understanding of why some cows live longer than others.

For this reason, the objective of this study was to evaluate the relationship between longevity with productive and reproductive efficiency variables of Nelore cows in grazing systems in the Bolivian tropics.

\section{Materials and Methods}

Retrospective data corresponding to the period between 1992 and 2019 were used for the research work belonging to the Cooperativa Agropecuaria Integral San Juan de Yapacaní (CAISY) located in Japanese Community San Juan $16^{\circ} 59^{\prime} 0^{\prime \prime}$ south latitude, 6358'0" west longitude and Technology Center on Agriculture and Livestock in Bolivia (FUNDACION CETABOL) in Japanese Community Okinawa $\left(17^{\circ} 13^{\prime} 12^{\prime \prime}\right.$ south latitudes, 62 53'39" west longitude) Santa Cruz, Bolivia. The communities are located at $286 \mathrm{~m}$ above sea level and they present a tropical climate, with significant rains in most months of the year and a short dry season with little effect on the general climate.

The annual average temperature is $24.3^{\circ} \mathrm{C}$ with average rainfall of $1805 \mathrm{~mm}$ in Japanese Community San Juan and $986 \mathrm{~mm}$ in Japanese Community Okinawa, Santa Cruz. Rainfall is minimal in the month of July, with average values of $50 \mathrm{~mm}$. The wettest month in January with an average rainfall of $330 \mathrm{~mm}$. The highest average temperatures correspond to the month of January, with values of $26.5^{\circ} \mathrm{C}$ and the lowest to the month of July with records of $20.7^{\circ} \mathrm{C}$.

\section{Animals}

The data corresponding to 774 Nelore breed cows, primiparous and multiparous discarded with a total of 4050 calvings were used. The primiparous cows calve between the months of May and July of each year, while the rest do so between the months of July and September. Weaning occurs between seven and eight months in two or three stages depending on the body condition and general state. Gynecological control is performed routinely at weaning, by a technical advisor, as well as health. Natural conceptions were used in the years analyzed.

\section{Feeding and Management}

The herd was fed grazing managed in intensive conditions, on 311 hectares with cultivated pastures Brachiaria brizantha (10 to $18 \mathrm{t} / \mathrm{ha} /$ year of DM) Brachiaria decumbens (8 to $12 \mathrm{t} / \mathrm{ha} /$ year of DM), Brachiaria humidicola (8 to $10 \mathrm{t} / \mathrm{ha} / \mathrm{year}$ of DM), Brachiaria dictyoneura (8 to $10 \mathrm{t} / \mathrm{ha} /$ year of DM), Cynodon dactylon (10 to $20 \mathrm{t} / \mathrm{ha} / \mathrm{year}$ of $\mathrm{DM}$ ) and Panicum maximum $c v$ mombaza (20 to $28 \mathrm{t} / \mathrm{ha} / \mathrm{year}$ of DM) (ESCASAN, 2020).

\section{Body Weight Record}

The cows had at least two individual weight controls every year. The weighing of the animals was always carried out at the same time $(8: 00 \mathrm{am})$. The calves were weighed with a brand manual scale (POCKET BALANCE; Made in Germany) on the same day of birth. From two months of age, calves and dams were weighed with a brand electronic scale (ICONIX New Zealand Ltd.).

\section{Variables Used}

Variables productive

Date of Birth (DB)

First Calving Date (FCD)

Number of Calvings (NC): Sum of deliveries in their productive life

Cow Live Weight (LW) in kg: Average weight of cow of all weights of her lactation.

Calf weight at Birth (CWB) in kg: Average calf weight at birth for all calvings

Calf Weight at Weaning (CWW) in kg: Average calf weight at weaning of all calvings

Total Calf Weight (TCW) in kg: Sum of calf weights at weaning of all calvings

Age at First Calving (AFC) in months: The age at first calving (date of birth - date of first calving)

Longevity (L) in days: Date of discard or death - date of birth in days

Variable reproductive

Calving Interval (CI) in days: Average calving interval of all calvings. 


\section{Statistic Analysis}

The cows were grouped by date of birth, where they were ordered in three decades [(1985-1995; 1995-2005; 2005-2015)]. A multiple regression model was applied that describes longevity as a function of the other variables. To select the best predictors, the stepwise method is used based on the bidirectional approach, which in each step tests which variables are excluded or included in the model. The quality of the model will be evaluated using the Akaike criteria. The interpretation of the model was carried out based on the estimated regression coefficients. The statistical analyzes were carried out with the R 4.0.0

\section{Results}

\section{Descriptive Analysis}

Table 1 shows the descriptive results of the variables studied, showing that cows born in the year (1985-1995) are those that arrive later to have their first calving, have greater calving intervals, have greater longevity, similar weaning weight of calves, lower birth weight of calves, lower live weight and higher total calf weight. While cows born in the year (2005-2015) are those that arrive younger to have their first calving, they have shorter calving intervals, have shorter longevity, similar wearing weight of calves, greater birth weight of calves, intermediate live weight and lower total calf weight.

Table 1: Descriptive measures of position and dispersion for variables considered in the study

\begin{tabular}{|c|c|c|c|c|c|c|c|c|c|c|c|}
\hline Variable & Year of birth & $\mathrm{N}$ & Mean & S.D. & $\mathrm{CV}$ & Mín. & Máx. & Median & Q1 & Q3 & I.Q.R \\
\hline \multirow[t]{3}{*}{ Age first calving (days) } & $(1985,1995)$ & 146 & 1383 & 338 & 24 & 777 & 2757 & 1319 & 1163 & 1597 & 434 \\
\hline & $(1995 ; 2005)$ & 330 & 1066 & 157 & 15 & 695 & 1848 & 1056 & 949 & 1124 & 175 \\
\hline & $(2005 ; 2015)$ & 298 & 1030 & 128 & 12 & 757 & 1511 & 1026 & 927 & 1098 & 171 \\
\hline \multirow[t]{3}{*}{ Calving interval (days) } & $(1985,1995)$ & 146 & 460 & 80 & 17 & 324 & 827 & 443 & 415 & 486 & 71 \\
\hline & $(1995 ; 2005)$ & 330 & 455 & 99 & 22 & 321 & 1092 & 429 & 390 & 487 & 97 \\
\hline & $(2005 ; 2015)$ & 298 & 437 & 87 & 20 & 293 & 836 & 414 & 374 & 469 & 94 \\
\hline \multirow[t]{3}{*}{ Longevity (days) } & $(1985,1995)$ & 146 & 4174 & 1058 & 25 & 1983 & 6335 & 4167 & 3266 & 5161 & 1895 \\
\hline & $(1995 ; 2005)$ & 330 & 3275 & 1268 & 39 & 1475 & 6852 & 2995 & 2173 & 4356 & 2183 \\
\hline & $(2005 ; 2015)$ & 298 & 2535 & 832 & 33 & 1305 & 4813 & 2329 & 1895 & 3041 & 1146 \\
\hline \multirow[t]{3}{*}{ Calf weight at weaning $(\mathrm{kg})$} & $(1985,1995)$ & 146 & 214 & 22 & 10 & 147 & 284 & 216 & 202 & 227 & 25 \\
\hline & $(1995 ; 2005)$ & 330 & 218 & 23 & 11 & 102 & 286 & 221 & 205 & 234 & 29 \\
\hline & $(2005 ; 2015)$ & 298 & 216 & 25 & 11 & 138 & 367 & 218 & 201 & 232 & 30 \\
\hline \multirow[t]{3}{*}{ Calf weight at birth $(\mathrm{kg})$} & $(1985,1995)$ & 146 & 32 & 3 & 8 & 26 & 40 & 33 & 31 & 34 & 3 \\
\hline & $(1995 ; 2005)$ & 330 & 35 & 4 & 11 & 24 & 47 & 35 & 32 & 37 & 5 \\
\hline & $(2005 ; 2015)$ & 298 & 36 & 4 & 10 & 28 & 50 & 36 & 34 & 38 & 4 \\
\hline \multirow[t]{3}{*}{ Live weight of cow $(\mathrm{kg})$} & $(1985,1995)$ & 146 & 499 & 59 & 12 & 384 & 647 & 493 & 452 & 537 & 84 \\
\hline & $(1995 ; 2005)$ & 330 & 520 & 55 & 11 & 325 & 653 & 524 & 480 & 558 & 78 \\
\hline & $(2005 ; 2015)$ & 298 & 503 & 54 & 11 & 342 & 651 & 502 & 464 & 537 & 73 \\
\hline \multirow[t]{3}{*}{ Total calf weight $(\mathrm{kg})$} & $(1985,1995)$ & 146 & 1450 & 609 & 42 & 362 & 3480 & 1445 & 944 & 1926 & 982 \\
\hline & $(1995 ; 2005)$ & 330 & 1227 & 729 & 59 & 238 & 3315 & 1074 & 593 & 1760 & 1166 \\
\hline & $(2005 ; 2015)$ & 298 & 862 & 458 & 53 & 300 & 2331 & 733 & 485 & 1074 & 588 \\
\hline
\end{tabular}

Mean: Arithmetic mean, S.D.: Standard deviation, CV: Coefficient of variation, Min.: Minimum

Max: Maximum, Median: Median value, Q1: Quartile one, Q3: quartile three, I.Q.R: INTERQUARTILE range.

Table 2: Analysis of variance of year of birth, year at first calving, calving interval and total weight

\begin{tabular}{lrrrrl}
\hline & Df & \multicolumn{1}{c}{ Sum Sq } & Mean Sq & F value & $\operatorname{Pr}(>\mathrm{F})$ \\
\hline Year of birth & 2 & 272333432 & 136166716 & 2035.0752 & $<2.2 \mathrm{e}-16^{* * *}$ \\
AFC (days) & 1 & 312 & 312 & 0.0047 & 0.945598 \\
CI (days) & 1 & 1463545 & 1463545 & 21.8734 & $3.448 \mathrm{e}-06 * * *$ \\
Total weight $(\mathrm{kg})$ & 1 & 829466733 & 829466733 & 12396.7677 & $<2.2 \mathrm{e}-16^{* * *}$ \\
YB*AFC & 2 & 522340 & 261170 & 3.9033 & $0.020582 *$ \\
YB*CI & 2 & 687548 & 343774 & 5.1379 & $0.006076 * *$ \\
YB*Total weight(kg) & 2 & 200319 & 100159 & 1.4969 & 0.224477 \\
Error & 758 & 50717719 & 66910 & & \\
\hline
\end{tabular}

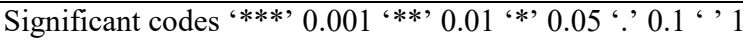

AFC: Year at First Calving

CI: Calving Interval

YB: Year of Birth

YB*AFC: Year of Birth *Age of First Calving

YB*CI: Year of Birth *Calving Interval

YB*Total Weight: Year of Birth *Total Weight
} 


\section{Model Results}

Table 2 shows that there is a significant interaction between the year of birth and the age at the first calving and the year of birth and the variable calving interval. That is, the relationship between age at first birth and life length is not the same for all birth year intervals. The same happens with the relationship length of life and the calving interval. Regarding the variable total weight $(\mathrm{kg})$, it is significant by itself but its interaction with year of birth is not significant.

In Table 4 the results of the equations can be interpreted as follows.

\section{For the Year (1985-1995) the Length of Life}

- It increases 0.95 days on average when the Age at First Birth increases by one unit, leaving the values of the other variables fixed

- Increases 2.99 days on average per unit increase in the Calving Interval, setting the values of the other variables

- Increases 1.83 days on average per unit increase in total calf weight, leaving the values of the other variables fixed

\section{For the Year (1995-2005) the Length of Life}

- It increases 0.66 days on average when the Age at first birth increases by one unit, leaving the values of the other variables fixed
- Increases 1.85 days on average per unit increase in the Calving Interval, setting the values of the other variables

- Increases 1.75 days on average per unit increase in total calf weight, leaving the values of the other variables fixed

\section{For the Year (2005-2015): The Length of Life}

- It increases 0.68 days on average when the age at first birth increases by one unit, leaving the values of the other variables fixed

- Increases 1.78 days on average per unit increase in the calving interval, setting the values of the other variables

- Increases 1.77 days on average per unit increase in Total Calf Weight, leaving the values of the other variables fixed

In Fig. 2 it is observed that the predicted values of the length of life as a function of the calving interval behave in a similar way as for the previous case (Fig. 1). The relationship between the calving interval and the length of life is positive in the three intervals of year of birth. However, the slope or increase in the average life length for each unit increase in the calving interval is greater for cows born between 1985-1995 than for those born between 1995-2005 and 2005-2015 (p-value $=0.006076)$.

Table 3: Estimation of the model parameters for the regressor variables

\begin{tabular}{|c|c|c|c|c|c|}
\hline & Estimate & Std. Error & $\mathrm{t}$ value & $\operatorname{Pr}(>|t|)$ & Signif \\
\hline Intercept & $-1.162 \mathrm{e}+03$ & $2.010 \mathrm{e}+02$ & -5.783 & $1.07 \mathrm{e}-08$ & $* * *$ \\
\hline Year of Birth $(1995 ; 2005)$ & $7.368 \mathrm{e}+02$ & $2.364 \mathrm{e}+02$ & 3.116 & 0.001900 & $* *$ \\
\hline Year of Birth $(2005 ; 2015)$ & $6.925 \mathrm{e}+02$ & $2.560 \mathrm{e}+02$ & 2.705 & 0.006992 & $* *$ \\
\hline Age at First Calving & $9.532 \mathrm{e}-01$ & $6.672 \mathrm{e}-02$ & 14.285 & $<2 \mathrm{e}-16$ & $* * *$ \\
\hline Calving Interval & $2.985 \mathrm{e}+00$ & $3.126 \mathrm{e}-01$ & 9.549 & $<2 \mathrm{e}-16$ & $* * *$ \\
\hline Total Calf Weight & $1.834 \mathrm{e}+00$ & $4.109 \mathrm{e}-02$ & 44.638 & $<2 \mathrm{e}-16$ & $* * *$ \\
\hline Year of Birth $(1995 ; 2005)$ : Age at First Calving & $-2.896 \mathrm{e}-01$ & $1.132 \mathrm{e}-01$ & -2.558 & 0.010731 & $*$ \\
\hline Year of Birth $(2005 ; 2015)$ : Age at First Calving & $-2.743 e-01$ & $1.370 \mathrm{e}-01$ & -2.002 & 0.045650 & $*$ \\
\hline Year of Birth (1995; 2005): Calving Interval & $-1.140 \mathrm{e}+00$ & $3.463 \mathrm{e}-01$ & -3.293 & 0.001039 & $* *$ \\
\hline Year of Birth (2005; 2015): Calving Interval & $-1.207 e+00$ & $3.575 \mathrm{e}-01$ & -3.377 & 0.000771 & $* * *$ \\
\hline Year of Birth (2005; 2015): Total Calf Weight & $-7.928 \mathrm{e}-02$ & $4.586 \mathrm{e}-02$ & -1.729 & 0.084277 & . \\
\hline Year of Birth `[2005; 2015): Total Calf Weight & $-6.080 e-02$ & $5.296 \mathrm{e}-02$ & -1.148 & 0.251321 & \\
\hline
\end{tabular}

Significant Codes: *** 0.001;** 0.01;*0.05; . 0.1; ' 1

Residual standard error: 258.7 on 758 degrees of freedom

Multiple R-squared: 0.9561, Adjusted R-squared: 0.9555

F-statistic: 1501 on 11 and $758 \mathrm{DF}$, p-value: $<2.2 \mathrm{e}-16$

Table 4: Intercept and estimated slopes for each birth year interval according to the model used

\begin{tabular}{llll}
\hline & Year (1985-1995) & Year (1995-2005) & Year (2005-2015) \\
\hline Intercept & $-1162,000000$ & $-425,200000$ & $-469,500000$ \\
Age at first calving & 0,953200 & 0,663600 & 0,678900 \\
Calving interval & 2,985000 & 1,845000 & 1,778000 \\
Total calf weight & 1,834000 & 1,754720 & 1,773200 \\
\hline
\end{tabular}




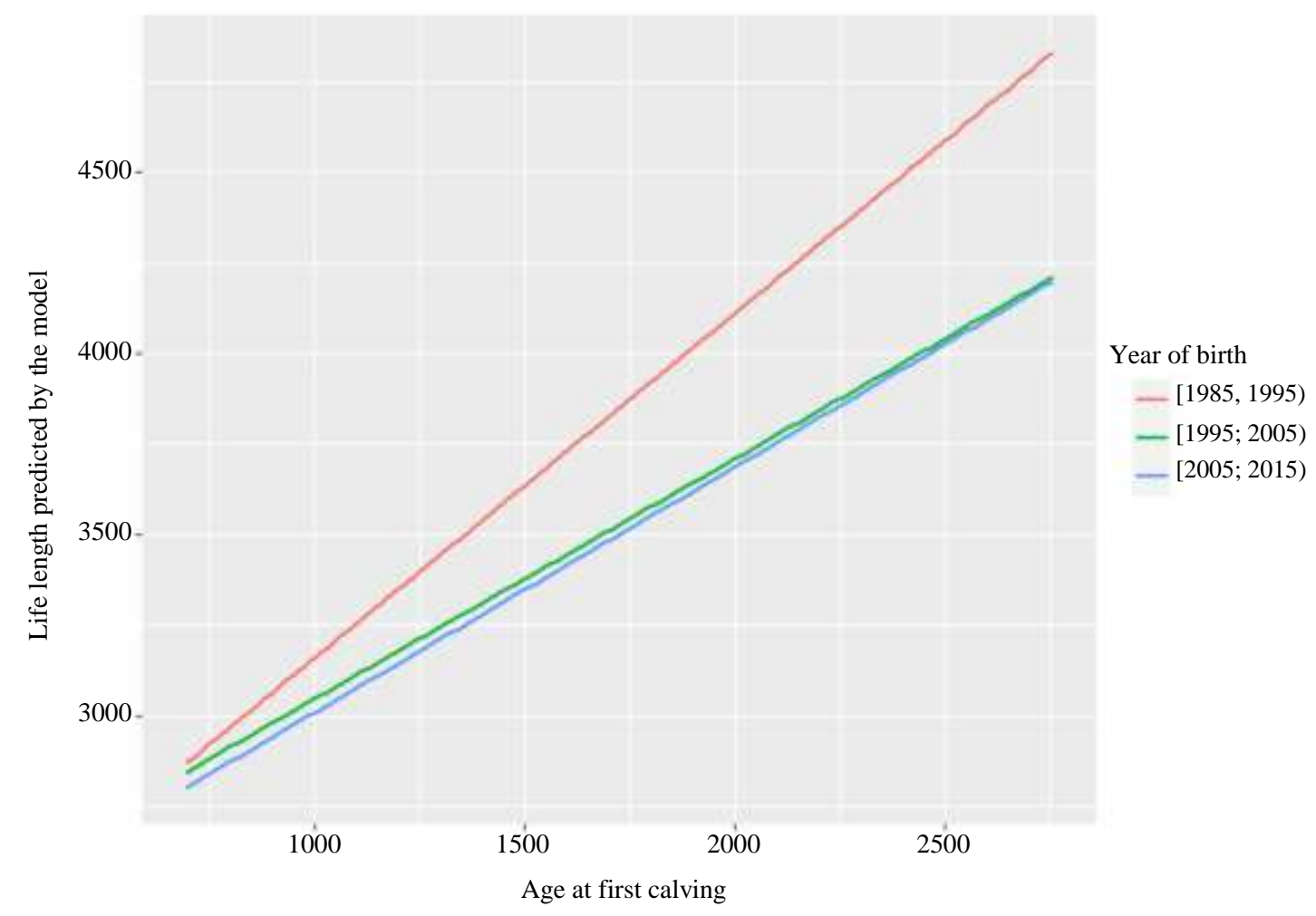

Fig. 1: Age at first birth Vs life length values predicted by the model, leaving the values of the other variables fixed

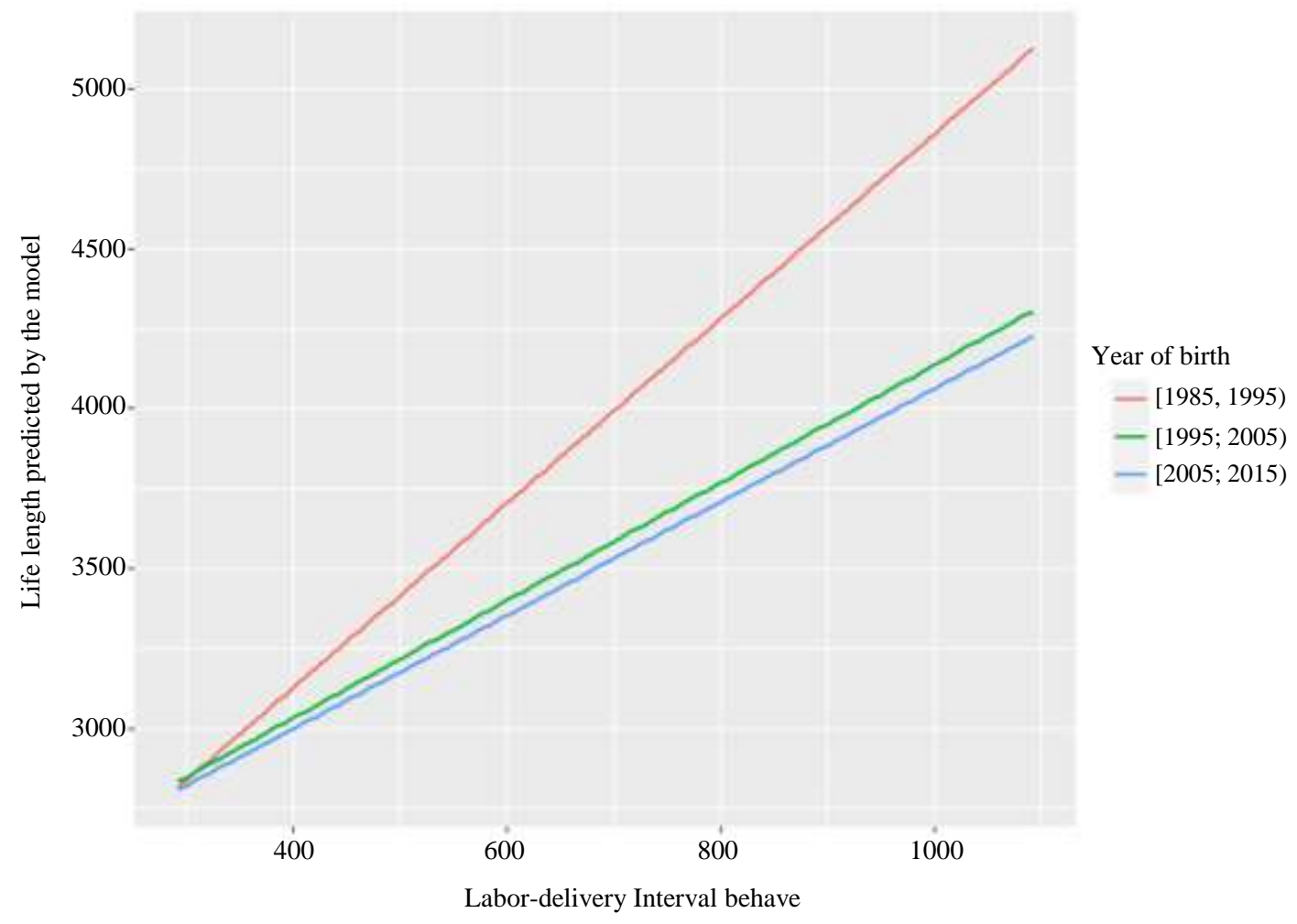

Fig. 2: Labor-delivery interval Vs life length values predicted by the model, leaving the values of the other variables fixed 


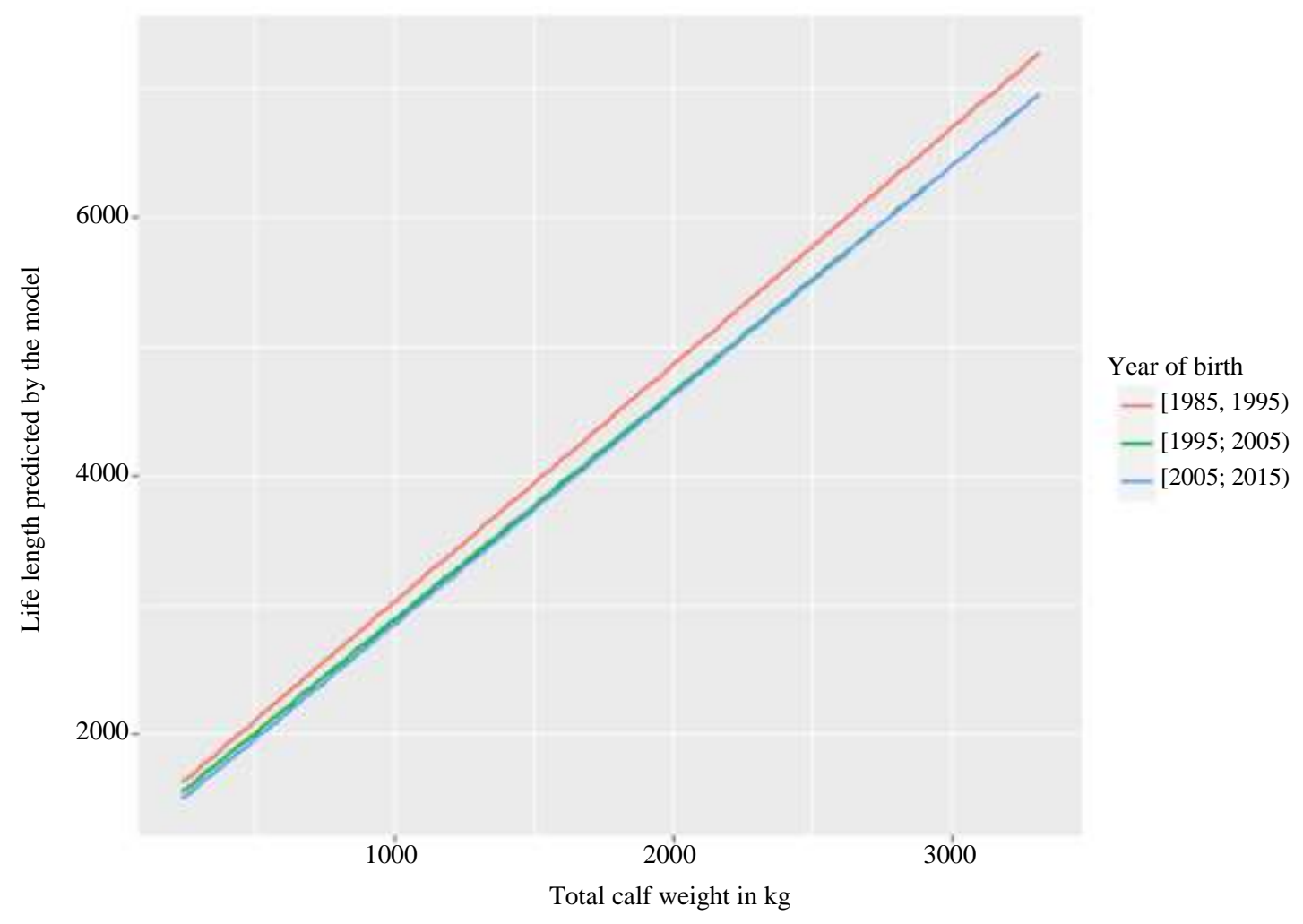

Fig. 3: Total calf weight $(\mathrm{kg})$ Vs life length values predicted by the model, leaving the values of the other variables fixed

In Fig. 3 it can be seen that as the total calf weight in $\mathrm{kg}$ increases, the average life length also increases. However, since there is no significant interaction between total weight and year of birth ( $\mathrm{p}$-value $=0.224477$ ), the increase in average life length for each unit increase in total weight is similar in the three intervals of year of birth. That is, there is a linear relationship between total weight and life length ( $\mathrm{p}$-value $<2 \mathrm{e}-16)$.

\section{Discussion}

The period in which the cows remain productive is an important factor in the profitability of the systems, because their permanence and productivity affect production costs. Therefore, the profitability of beef cattle production is directly related to productive efficiency and costs (Bernardes et al., 2018). It is logical to expect that there are differences in the longevity of cows between different production systems, which may be associated with environmental factors, herd size and management (Segura-Correa et al., 2013). The results found in this study with respect to the ages at the first calving were different and significant with respect to the year of birth.

Where cows born in the decade 1985-1995 reached their first calving at 45 months, while in the other two decades $(1995-2005 ; 2005-2015)$ it was 34.9 and 33.7 months respectively. Observing a decrease in the age at first calving in the last two decades studied. The results for the decades 1995-2005 and 2005-2015 are below the 38.7 months found by (García et al., 2003) and are similar to the 35.6 months presented by (Flores and Ortiz, 2010) both in Nelore cattle. The age at first calving can influence the number of calvings of a cow during its useful life in the herd, because the greater sexual precocity of the cows would lead to a longer productive life (Nunez-Dominguez et al., 1991, Vukasinovic et al., 2001; Rogers et al., 2004; ArandaAvila et al., 2010). In this study, the results do not coincide with the aforementioned authors, since in the model estimates for the three periods studied, an increase in the age at first calving by one unit increases the longevity of the cows. The greater probability of a greater longevity of Nelore cows occurs when they arrive at an older age at the first calving.

This could be explained by a set of factors, including the environment in which they develop (nutritional and climatic). This means that those cows that manage to reach their first calving going through the difficulties that they had to overcome in the breeding and rearing stage, acquire a level of adaptation that allows them to face the different future calvings, in addition to being attributed to the greater rusticity and adaptability of the race analyzed to the tropical climate. Marulanda (1996), 
reported that the ideal is that the age at first calving coincides when the heifer is mature enough to withstand the stress of lactation, making it clear that there would not be a target time to meet since it could be subject to the factors previously cited.

To be efficient in the production of cows for meat, it is necessary to identify profitable females and for that, reproductive traits should be included when the objective of selection is the highest economic profitability for the breeder (Oyama et al., 2004; Laske et al., 2012; de Lima Silva et al., 2019). Brumatti et al. (2011) showed the need to readjust the current selection indices, thus giving greater emphasis to reproductive traits, since they are economically more relevant. The results found in this study regarding the calving interval were different and significant regarding the year of birth.

Where cows born in the decade 1985-1995 had a greater calving interval than in the other two decades (1995-2005; 2005-2015). The calving interval values found are below to those reported by (Perotto et al., 2006), where they reported that the calving interval in Nelore herds is 492 days and 483 days found by (McManus et al., 2002), also equivalent to the 465 days reported by (Silveira et al., 2004). In this study, the model estimates for the three periods studied (Table 3) showed that an increase of one unit in the calving interval increases the longevity of the cows.

The interpretation of this result may be that the cows go through traumatic nutritional and environmental situations (few or excessive rains, high temperatures) that do not allow them to carry out a gestation that allows a shorter calving interval, although this does not affect their longevity of the themselves, showing that in this environment the cows the longest intervals are part of their adaptation.

The variable total calf weight in $\mathrm{kg}$ is the third variable that explains the model, being the most important from the productive point of view and that in general this type of aggregate indicator is not used for the analysis of the systems. It is necessary for the cows to achieve the highest amount of $\mathrm{kg}$ of total calf weight at the end of their productive life, being within the model the one with the greatest economic impact and also, having the need for the cows to meet the highest life expectancy possible.

The results found in this study regarding the total calf weight were different and significant with respect to the year of birth. Where cows born in the decade of 1985-1995 had a higher total calf weight, than in the other two decades (1995-2005; 2005-2015), the latter being the one with the lowest value. The model estimates for the three periods studied showed that an increase in one unit in the calving interval increases the longevity of the cows. These results reinforce what was expressed by (Parish, 2010) where the herds made up of a higher proportion of mature cows tend to have a higher percentage of weaned calves ( $\mathrm{kg}$ of total calf), reduce production costs and increase the sale of kilograms of calf total.

In addition, a greater number of adult cows in the herd close to $80 \%$, would allow from a zootechnical concept that the traits associated with biological efficiency such as longevity and reproduction of the animals contribute to greater sustainability to the productive system (Ikeda et al., 2020). Nunez-Dominguez et al. (1990) suggested that the cumulative production of weaned calves per replacement female is an appropriate statistic that takes into account the fertility, maternal instinct and longevity of the cow to measure the reproductive behavior of the evaluated herd.

The results found in this study allow us to reflect that in livestock production and specifically in breeding in systems with very little environmental control, care would have to be taken just by thinking of maximizing weaning weight as the only objective, instead, it should be more comprehensive vision and think about the inclusion of the entire life of the cow (longevity), which would imply including reproductive success and rearing efficiency in the analysis.

\section{Conclusion}

It is concluded that it was possible to find a model that explained that the greater longevity of Nelore cows in a grazing system in the Bolivian tropics and it was related to the older age at first calving, the greater calving interval and the greater $\mathrm{kg}$ of weights of calves.

This will imply in the future replicating the model found to be able to explain the longevity of the cows in the systems that are required.

\section{Acknowledgment}

This work was supported by the Technology Center on Agriculture and Livestock in Bolivia (Fundacion Cetabol) in Japanese Community Okinawa and Cooperativa Agropecuaria Integral San Juan de Yapacaní, Santa Cruz, Bolivia

\section{Author's Contributions}

Atsuko Ikeda: Corresponding author and coordination of the study.

Ivana Barbona: Participated in all experiments, coordinated the data-analysis.

Yoichiro Hayashi: Designed the research plan and organized the study.

Juan Antonio Pereira: Organized and reviewed the article.

Pablo Roberto Marini: Contributed in planning the strategy and reviewing the article. 


\section{Ethics}

The authors confirm that the present article is original and no ethical issues related to this study.

\section{References}

Aranda-Avila, I., Magaña-Monforte, J. G., \& SeguraCorrea, J. C. (2010). Effects of breed type and age at first calving on length of productive life in a cowcalf system in Southeastern Mexico. Tropical animal health and production, 42(8), 1737-1741.

Bernardes, P. A., DP, M., Reis, R. A., \& Malheiros, E. B. (2018). A review of three important points that can improve the beef cattle productivity in Brazil.

Brumatti, R. C., Ferraz, J. B. S., Eler, J. P., \& Formigonni, I. B. (2011). Desenvolvimento de índice de seleção em gado corte sob o enfoque de um modelo bioeconômico. Archivos de zootecnia, 60(230), 205-213.

Carrizales Montealegre, J. J. (2005). Relación entre la edad, el peso y la eficiencia reproductiva en hembras Brahaman de competencia.

Carvalho, C. V. D., \& Bittencourt, T. C. C. D. (2015). Breeding objectives for a Nellore cattle rearing system. Pesquisa Agropecuária Brasileira, 50(9), 814-820.

Dakay, I., Márton, D., Bene, S., Kiss, B., Zsuppan, Z., \& Szabo, F. (2006). The age at first calving and the longevity of beef cows in Hungary. Archives Animal Breeding, 49(5), 417-425.

Damiran, D., Larson, K. A., Pearce, L. T., Erickson, N. E., \& Lardner, B. H. (2018). Effect of calving period on beef cow longevity and lifetime productivity in western Canada. Translational Animal Science, 2(suppl_1), S61-S65.

de Lima Silva, T., Carneiro, P. L. S., Ambrosini, D. P., Lôbo, R. B., Martins Filho, R., \& Malhado, C. H. M. (2019). Genotype-environment interaction in the genetic variability analysis of reproductive traits.

Diskin, M. G., \& Kenny, D. A. (2014). Optimising reproductive performance of beef cows and replacement heifers. Animal, 8(s1), 27-39.

ESCASAN. (2020). Grass Seed Matsuda. ESCASAN SA. https://www.escasan.com.ni/etiquetaproducto/matsuda/

Flores, V., \& Ortiz, T. (2010). Determinación de los parámetros reproductivos de los vientres nelore en la estancia parabano (Provincia Cordillera Dpto. Santa Cruz) (Doctoral dissertation, Tesis de grado, Universidad Autónoma Gabriel René Moreno). http://www.fcv.uagrm.edu.bo/sistemabibliotecario/d oc_tesis/FLORES\%20V.\%20DAVID-20101104173309.pdf)
García, G. A., Maldonado-Estrada, J. G., \& López, J. G. (2003). Caracterización productiva y reproductiva de las explotaciones ganaderas del bajo cauca y el litoral atlántico antioqueños. II. Comportamiento de cuatro grupos raciales Bos indicus en un sistema de bosque seco tropical (bs-T). Revista Colombiana de Ciencias Pecuarias, 16(2), 117-125.

Holgado, F. D., \& Rabasa, A. E. (1999). Eficiencia reproductiva de diferentes grupos raciales de bovinos para carne en el subtrópico argentino;[Reproductive efficiency in different cattle breedtypes in the Argentino subtropic]. Zootecnia Tropical (Venezuela). (, 17(2), 243-259.

Ikeda, A., Barbona, I., Hayashi, Y., Pereira, J. A., \& Marini, P. R. (2019). Longevity of Nelore Cows of the Bolivian Tropics. Is It Possible to Explain It Through Productive Variables?. Sustainable Agriculture Research, 8(526-2020-554), 28-34.

Ikeda, A., Garzón, J. P., Moyano, J. C., Leib, S., \& Marini, P. R. (2020). Fruchtbarkeits- und Aufzuchtleistung von Nelore-Rindern verschiedenen Alters bei Weidehaltung in den bolivianischen Tropen. Zuchtungskunde. 92, 125-132.

Laske, C. H., Teixeira, B. B. M., Dionello, N. J. L., \& Cardoso, F. F. (2012). Breeding objectives and economic values for traits of low input family-based beef cattle production system in the State of Rio Grande do Sul. Revista Brasileira de Zootecnia, 41(2), 298-305.

Marulanda, E. (1996). Evaluación de la edad del servicio y su incidencia en la productividad y reproductividad de las novillas Cebú. Revista El Cebú ASOCEBÚ, 43, 44-64.

McManus, C., Saueressig, M. G., Falcão, R. A., Serrano, G., Marcelino, K. R. A., \& Paludo, G. R. (2002). Componentes reprodutivos e produtivos no rebanho de corte da Embrapa Cerrados. Revista Brasileira de Zootecnia, 31(2), 648-657.

Nunez-Dominguez, R., Cundiff, L. V., Dickerson, G. E., Gregory, K. E., \& Koch, R. M. (1990). Heterosis for survival and dentition in Hereford, Angus, Shorthorn and crossbred cows. Journal of animal science, 69(5), 1885-1898.

Nunez-Dominguez, R., Cundiff, L. V., Dickerson, G. E., Gregory, K. E., \& Koch, R. M. (1991). Lifetime production of beef heifers calving first at two vs three years of age. Journal of Animal Science, 69(9), 3467-3479.

Orozco, A. C., Velásquez, E. F. P., Mesa, H., \& Velásquez, L. F. U. (2013). Relacion entre condicion corporal y espesor de grasa de cadera en vacas cebu en diferentes estados reproductivos. Revista Científica, 23(1), 42-47. 
Oyama, K., Katsuta, T., Anada, K., \& Mukai, F. (2004). Genetic parameters for reproductive performance of breeding cows and carcass traits of fattening animals in Japanese Black (Wagyu) cattle. Animal Science, 78(2), 195-201.

Parish, J. (2010). Beef Production Strategies. Extension Beef Cattle Specialist, Mississippi State University. Cattle Business in Mississippi.

Perotto, D., Abrahão, J. J. D. S., \& Kroetz, I. A. (2006). Intervalo de partos de fêmeas bovinas Nelore, Guzerá x Nelore, Red Angus x Nelore, Marchigiana $x$ Nelore e Simental x Nelore. Revista Brasileira de Zootecnia, 35(3), 733-741.

Rogers, P. L., Gaskins, C. T., Johnson, K. A., \& MacNeil, M. D. (2004). Evaluating longevity of composite beef females using survival analysis techniques. Journal of Animal Science, 82(3), 860-866.
Segura-Correa, J. C., Magaña-Monforte, J. G., Centurión-Castro, F., \& Segura-Correa, V. M. (2013). Efecto de grupo racial y edad al primer parto sobre el número de partos durante la vida útil de vacas cebú. Archivos de medicina veterinaria, 45(1), 41-44.

Silveira, J. C. D., McManus, C., Mascioli, A. D. S., Silva, L. O. C. D., Silveira, A. C. D., Garcia, J. A. S., \& Louvandini, H. (2004). Fatores ambientais e parâmetros genéticos para características produtivas e reprodutivas em um rebanho Nelore no estado do Mato Grosso do Sul. Revista Brasileira de Zootecnia, 33(6), 1432-1444.

Vukasinovic, N., Moll, J., \& Casanova, L. (2001). Implementation of a routine genetic evaluation for longevity based on survival analysis techniques in dairy cattle populations in Switzerland. Journal of Dairy Science, 84(9), 2073-2080. 